\title{
The role of aging upon $\beta$ cell turnover
}

\author{
Jake A. Kushner1,2 \\ ${ }^{1}$ McNair Medical Institute, Pediatric Diabetes and Endocrinology, Baylor College of Medicine, Houston, Texas, USA. \\ 2Texas Children's Diabetes and Endocrinology Center, Texas Children's Hospital, Houston, Texas, USA.
}

\begin{abstract}
Preservation and regeneration of $\beta$ cell endocrine function is a long-sought goal in diabetes research. Defective insulin secretion from $\beta$ cells underlies both type 1 and type 2 diabetes, thus fueling considerable interest in molecules capable of rebuilding $\beta$ cell secretion capacity. Though early work in rodents suggested that regeneration might be possible, recent studies have revealed that aging powerfully restricts cell cycle entry of $\beta$ cells, which may limit regeneration capacity. Consequently, aging has emerged as an enigmatic challenge that might limit $\beta$ cell regeneration therapies. This Review summarizes recent data regarding the role of aging in $\beta$ cell regeneration and proposes models explaining these phenomena.
\end{abstract}

\section{Insulin secretion governs glucose homeostasis and diabetes pathophysiology}

Insulin secretion is at the heart of the endocrine axis controlling glucose homeostasis, with additional roles that regulate metabolism, energy homeostasis, reproduction, skeletal physiology, somatic growth, and other core physiological functions. Deficient insulin action is a key component of the pathophysiology of both type 1 and type 2 diabetes. Type 1 diabetes results from autoimmune destruction of pancreatic $\beta$ cells, which decreases the total number of cells capable of secreting insulin and other hormones (1). Normal glucose homeostasis becomes disrupted in type 1 diabetes as a result of gradual reduction in $\beta$ cell mass and subsequent failure of the residual insulin-secreting $\beta$ cells to compensate. Traditional views of type 2 diabetes pathophysiology centered on resistance to peripheral insulin action as the primary driver of altered glucose homeostasis, informed by early observations of insulin resistance in type 2 diabetes (2). Defective $\beta$ cell function is another early hallmark of type 2 diabetes; abnormalities in insulin secretion have been documented in some individuals many years before the onset of overt type 2 diabetes $(3,4)$, and many have concluded that insufficient $\beta$ cell function also plays a central role in type 2 diabetes pathophysiology $(5,6)$. In the end, increased insulin demand combined with defective insulin secretion results in $\beta$ cells that are unable to adequately compensate for increased metabolic demand. Insufficient insulin secretion leads to ambient hyperglycemia, which worsens $\beta$ cell function and ultimately leads to a downward spiral of impaired glucose homeostasis and frank type 2 diabetes. Thus, insufficient $\beta$ cell function is a central component in the pathophysiology of both types of diabetes.

\section{$\beta$ cell regeneration as an antidiabetic therapeutic strategy}

$\beta$ cell replacement strategies have historically focused on transplantation of islets or engineered insulin-secreting cells, but have lately broadened to include studies aimed at regeneration of endogenous $\beta$ cell function. Recent developmental biology studies revealed that the vast majority of adult $\beta$ cells are derived from other $\beta$ cells in mice (7-9). This observation reinvigorated studies on mature $\beta$ cells, in the hope that such work would lead to the development of novel antidiabetes therapies (10), assuming that

Conflict of interest: The author has received research support from Merck, Pfizer, and Johnson \& Johnson and serves on a scientific advisory board of Johnson \& Johnson. Citation for this article: J Clin Invest. 2013;123(3):990-995. doi:10.1172/JCI64095. the underling cause of $\beta$ cell loss could be somehow overcome. However, substantial challenges remain to create safe and durable clinical therapies that robustly regenerate $\beta$ cell function. $\beta$ Cell selectivity is a notable concern, as some putative $\beta$ cell mitogenic signals may also promote growth of other cells. For example, the glucagon-like peptide receptor signals, which are putative $\beta$ cell regenerative signals, may also activate calcitonin-producing parafollicular cells (C cells) of the medullary thyroid (11).

\section{Aging impairs human $\boldsymbol{\beta}$ cell function}

Age-associated deteriorations in $\beta$ cell function may contribute to type 2 diabetes risk (Figure 1). The vast majority of patients diagnosed with the disease are in the fifth and sixth decades of life (12). The prevalence of gestational diabetes, which is closely related to type 2 diabetes, is similarly increased in mothers of advanced age (13). Moreover, islets from aged donors result in worse transplantation outcomes compared with those from young donors (14). Studies in humans suggest that aging may independently impair $\beta$ cell function (15-18). The mechanism of age-related $\beta$ cell dysfunction is difficult to discern, in that aging may exert a distinct influence on human $\beta$ cell turnover as well as function (Table 1). Indeed, Donath and colleagues report that islets from aged human donors have reduced amounts of $\beta$ cell turnover compared with those from younger donors (19).

\section{Age-dependent decline in cell cycle entry of $\beta$ cells}

Although rodent $\beta$ cells have traditionally been thought to undergo frequent turnover, recent studies suggest that cell cycle entry of $\beta$ cells may be severely limited in advanced age. A highly cited thymidine analog-labeling study by Finegood, Scaglia, and Bonner-Weir reported that $\beta$ cells replicated every $1-3$ months in young rats (20). However, our work reveals that $\beta$ cell turnover declines markedly by 12 months of age in mice (approximately $0.07 \%$ cell turnover per day) (21). Minimal $\beta$ cell proliferation has also been observed by other investigators in mice that were more than one year old $(22,23)$. Given that one year of age corresponds to approximately $40 \%$ of the natural life span of mice, these studies imply that $\beta$ cells in mature mammals might proliferate far less than previously appreciated. Indeed, landmark studies by Clark, Cnop, and colleagues reveal that human $\beta$ cells and $\alpha$ cells may also be very long lived $(24,25)$. The authors observed an age-dependent increase in lipofuscin content within human $\beta$ cells from autopsies, implying that human $\beta$ cell and $\alpha$ cell turnover occurs very infrequently. Similarly, thymidine analog incorporation 


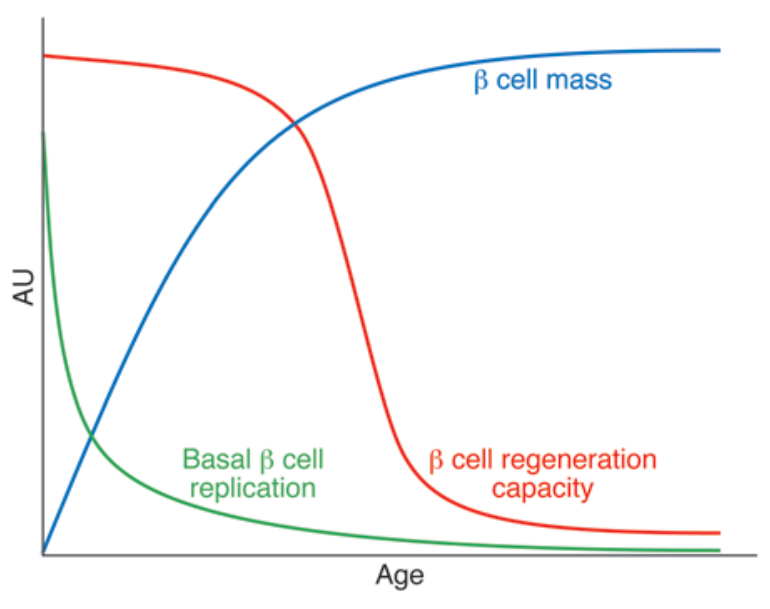

Figure 1

Proposed model of $\beta$ cell regeneration capacity. Basal $\beta$ cell replication capacity continuously decreases from early adulthood to middle age. As basal $\beta$ cell replication drops to very low levels, adaptive capacity is greatly decreased.

studies of human cancer patients by Perl et al. reveal minimal $\beta$ cell turnover in patients 31 years or older (26). $\mathrm{C}^{14}$ content studies in human islets from 48- and 80-year-old individuals indicated that $\beta$ cells were generated during the first 30 years of life for both samples (26). Butler and colleagues and Rhodes and colleagues have similarly reported very low rates of $\beta$ cell proliferation in human adult subjects, as detected by Ki67 content (27-29). Cumulatively, these studies challenge the notion of ongoing human $\beta$ cell turnover in adults, and suggest that human $\beta$ cells in adults are largely postmitotic. While $\beta$ cells could conceivably be replenished by a non-replicative source (direct cell conversion without cell division), this seems exceedingly unlikely, as no other adult mammalian cells are maintained by such a mechanism. Thus, human $\beta$ cells most likely survive a very long time, perhaps for the adult life span of the organism.

\section{Age-dependent changes in $\boldsymbol{\beta}$ cell regeneration capacity}

$\beta$ Cell regeneration therapies might have limited efficacy in aged mammals. Studies in young rodents have suggested that adult $\beta$ cell mass is under homeostatic control. Conditions of increased metabolic demand are accompanied by $\beta$ cell mass expansion (30). Similarly, a wide variety of $\beta$ cell reduction studies reveal that $\beta$ cells can regenerate in young rodents (31-35). By inference, these studies imply that $\beta$ cell regeneration might also be possible in human diabetic patients. However, the infrequent turnover of $\beta$ cells in aged mammals strongly implies that adaptive cell cycle entry of $\beta$ cells could be similarly restricted, which might limit $\beta$ cell regeneration. Prior to 2009 , virtually all $\beta$ cell regeneration studies examined very young mice in the first few months of life (31). While mice are sexually mature soon after weaning and are therefore technically adults, they are nevertheless very young ( 2 months of age is $\sim \%$ of natural life span). Indeed, young mice and rats continue to develop and grow until around 5 months $(36,37)$. We therefore tested $\beta$ cell regeneration capacity as a function of age, performing 50\% partial pancreatectomy (PPx) on mice across a broad range of ages and measuring BrdU incorporation. Consistent with previous studies, PPx-induced $\beta$ cell regeneration was robust in 1.5 -month-old mice. $\beta$ Cell regeneration was similarly robust in 8-month-old mice. In contrast, 12-month-old mice exhibited a much smaller increase in $\beta$ cell proliferation. Moreover, the PPx-induced regenerative response in $\beta$ cells was barely detectable or totally absent in two cohorts of older mice (14 months and 18 months, respectively) (38). Notably, PPx induced a pancreatic acinar cell regenerative response (increased BrdU incorporation) that was preserved into old age age (14 months and 18 months). Similarly, the regenerative response to low-dose streptozotocin was severely reduced in aged mice (14 months) compared with young rodents. We also tested exendin-4, a potent glucagon-like peptide, which may promote $\beta$ cell proliferation. Exendin- 4 had a minimal effect on the $\beta$ cells of aged mice (14 months) but increased $\beta$ cell proliferation in young mice. Importantly, Bhushan and colleagues also reported an age-dependent decline in $\beta$ cell proliferation in response to exendin- 4 or dietary fat-induced obesity by 7 months of age (39). Regeneration of $\beta$ cells may be similarly restricted in non-human primates. Butler and colleagues recently investigated the $\beta$ cell regenerative capacity of middle-aged velvet monkeys in response to streptozotocin (40). Although streptozotocin reliably induced diabetes, $\beta$ cell replication was not increased in the monkeys. Taken together, these studies indicate that $\beta$ cell regeneration capacity may severely decline with age in mammals.

\section{Can aged rodent $\beta$ cells regenerate in response to environmental cues?}

Recent studies suggest that $\beta$ cells may have some ability to enter the cell cycle. Kaufman and colleagues tested the islet-autonomous effects of aging upon $\beta$ cell regeneration by transplanting islets from young mice or old mice (20-24 months) into young recipients (41). As expected, $\beta$ cell replication was low when islets of either age group were transplanted into normoglycemic recipients $(\sim 0.5 \%$ per day in both young and old islet transplants). However, $\beta$ cell replication was robustly stimulated when islets from either young or old mice were transplanted into hyperglycemic recipients, with no difference in the regenerative response between young and old transplants ( $\sim 8 \%$ per day in both cohorts). Guo and colleagues recently reported similar studies, in which they found that exendin- 4 increased $\beta$ cell proliferation within islets from both young and old mice (>40 weeks) that were transplanted into young mice (42). Guo and colleagues also performed human islet xenotransplantation studies, but obtained a different result from their mouse islet transplant studies (42). Islets from young donors $(\leq 22$ years) exhibited substantial BrdU incorporation in $\beta$ cells (control, 4\%; exendin- 4 treated, $10 \%$ ), whereas few BrdU-positive $\beta$ cells were

\section{Table 1}

\section{$\beta$ Cell turnover}

Models of $\beta$ cell turnover

Ref.

Ongoing $\beta$ cell turnover

Age-dependent decline in $\beta$ cell turnover

20

Age-dependent decline in $\beta$ cell regeneration capacity

Insufficient mitogenic stimulus in aging $\beta$ cells

Regenerative capacity of $\beta$ cells present

but reduced with age

Age-dependent increase of CDKIs in $\beta$ cells

21-26

38,39

41

22,43

Increased length of cell cycle in aged $\beta$ cells
$39,43,47,48$,

$55,56,58$

8,60 


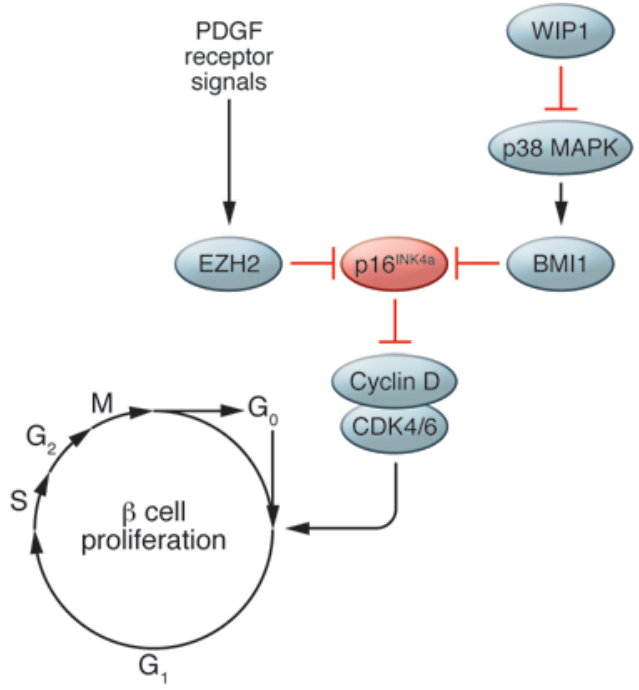

\section{Figure 2}

Molecular regulation of reduced cell cycle entry within aged $\beta$ cell replication. p16 INK4a regulates cell cycle entry of aged $\beta$ cells, presumably via D-type cyclins and the cyclin-dependent kinases CDK4 and CDK6, and is subject to potent negative regulation by the polycomb proteins EZH2 and BMI1. PDGF receptor signals seem to stimulate EZH2. Similarly, p38 MAPK may stimulate BMI1. p38 MAPK is inhibited by the WIP1 phosphatase.

detected within islets from aged donors ( $\geq 34$ years). In 2-year-old hyperglycemic mice, Bulavin and colleagues observed streptozotocin-induced $\beta$ cell proliferation (43). Similarly, Dor and colleagues observed small (but statistically significant) increases in $\beta$ cell proliferation in 21- and 25-month-old mice following diphtheria toxin-driven $\beta$ cell death, a provocative stimulus (22). Importantly, none of the studies were able to assess whether increases in $\beta$ cell proliferation translated to increased $\beta$ cell mass. Nevertheless, these studies indicate that $\beta$ cells from aged mammals might, in some situations, be coaxed into the cell cycle.

\section{Age-dependent regulation of the cell cycle by p16}

Considerable progress has been made in unraveling the molecular regulation of $\beta$ cell proliferation as well as the mechanisms of age-dependent changes in cell cycle entry of $\beta$ cells (Figure 2 and refs. 44-46). p16 ${ }^{\mathrm{INK} 4 \mathrm{a}}$, a cyclin-dependent kinase inhibitor (CDKI) encoded by the Cdkn2a locus, has emerged as a key control point for cell cycle entry of $\beta$ cells, along with the molecular regulators of this pathway. Sharpless and colleagues observed that $p 16^{I N K 4 a}$ expression correlated with increased age in a variety of mouse tissues, including islets (47). Proliferation of $\beta$ cells was reduced in mice with an additional copy of $p 16^{I N K 4 a}$ (48). Conversely, $\beta$ cell proliferation was increased in $p 16^{\text {INK4a }}$ knockout mice. Thus, p16 INK4a increases with age and appears to mediate an age-associated decline in the replicative capacity of mouse islets. This work, in combination with studies of $\mathrm{p}^{16^{\mathrm{INK}} 4 \mathrm{a}}$ in neural stem cells and hematopoiesis $(49,50)$, reveals that the effects of aging on cell cycle exit could be due to high levels of CDKIs. Moreover, genomewide association studies identified an association between SNPs near Cdkn2a and increased risk of type 2 diabetes (51-53). In addition, Alonso and colleagues recently observed that free fatty acids induce $\mathrm{p} 16^{\mathrm{INK} 4 \mathrm{a}}$ expression in islets, which may slow down cell cycle progression of $\beta$ cells in young mice (54). Thus $\mathrm{p} 16^{\mathrm{INK} 4 \mathrm{a}}$ could be a potential link between aging, metabolic derangements, and $\beta$ cell failure in type 2 diabetes.

\section{Epigenetic control of cell cycle regulators in aged islets} Several investigators have begun to unravel how differential CDKI expression occurs in aged islets. Bhushan and colleagues demonstrated that aging was associated with declining expression of $B$ lymphoma Mo-MLV insertion region 1 homolog (BMI1) (55), a chromatin-regulating polycomb group protein. Decreased BMI1 expression was associated with derepression of the $p 16^{\text {INK4a }}$ locus in islets, with differential histone modifications noted in Bmi1 knockout islets. Bmil knockout mice exhibited reduced $\beta$ cell mass and modest glucose intolerance, akin to accelerated aging $(39,55)$. Kim and colleagues similarly studied the role of enhancer of zeste homolog 2 (EZH2), another polycomb group protein (56). Islet EZH2 expression decreased with age, which was associated with derepression of the $p 16^{I N K 4 a}$ locus. Ezh2 knockout islets had increased $\mathrm{p} 16^{\mathrm{INK} 4 \mathrm{a}}$ expression, reduced $\beta$ cell proliferation, and subsequent reduction of $\beta$ cell mass. Together these studies reinforce the idea that the $\mathrm{p} 16^{\mathrm{INK} 4 \mathrm{a}}$ critically regulates $\beta$ cell mass expansion in an age-associated manner. Moreover, they reveal that epigenetic regulation may have a powerful role in this process and in diabetes pathophysiology as a whole (57).

\section{Mitogenic regulation of cell cycle entry in aged $\beta$ cells}

Although considerable attention has been given to potential $\beta$ cell mitogenic signals in young rodents, investigators have begun to question how relevant these studies are to human $\beta$ cell mass expansion $(44,46)$. The role of mitogenic signaling in age-dependent cell cycle exit of $\beta$ cells has received little attention. However, a study by Bulavin and colleagues revealed that p38 MAPK signals may influence CDKI expression in aged islets (43). The authors studied aged $p 38 M A P K$ mutant mice (22-25 months old) that expressed a dominant-negative allele that disrupts p38 MAPK signals. The mice had reduced islet expression of $\mathrm{p} 16^{\mathrm{INK} 4 \mathrm{a}}, \mathrm{p} 19^{\mathrm{Arf}}$, and other CDKIs, as well as increased $\beta$ cell proliferation. Middle-aged p38MAPK mutant mice (10-12 months) had partially rescued streptozotocin-induced $\beta$ cell regeneration. Moreover, wild-type p53-induced phosphatase 1 (WIP1) seemed to oppose p38 MAPK in islets. Islets from Wip1-null mice had increased $\mathrm{p} 16^{\mathrm{INK} 4 \mathrm{a}}$, and islets from middle-aged WIP1-overexpressing transgenic mice (1113 months) exhibited reduced $\mathrm{p} 16^{\mathrm{INK} 4 \mathrm{a}}$ as well as improved regenerative capacity after streptozotocin. This study therefore suggests a mechanistic link between WIP1, p38 MAPK, and p16 $6^{\text {INK4a }}$ in age-dependent cell cycle exit in islets.

The upstream signals that influence the age-dependent epigenetic regulation of $\beta$ cell regeneration have until recently been mostly unknown. In a striking series of studies, Kim and colleagues recently showed how PDGF signals influence $\beta$ cell proliferation and regeneration in an age-dependent manner (58). PDGF receptors and ligand were expressed in neonatal islets but declined thereafter in an age-dependent manner. PDGF treatment increased $\beta$ cell proliferation in cultured human islets from juvenile donors, but not in islets from adults. PDGF-deficient islets from young mice had reduced $\beta$ cell proliferation, with a subsequent reduction in $\beta$ cell mass. Conversely, transgenic PDGF receptor activation increased $\beta$ cell proliferation and expanded $\beta$ cell mass. PDGF receptor signals seem to act in part via EZH2, as Ezh2 gene deletion abrogated the enhanced $\beta$ cell proliferation associated with 
PDGF receptor activation. Taken together, these studies suggest that an age-dependent decline in PDGF signals might influence $\beta$ cell replication. Moreover, they imply that interventions that augment PDGF signals might stimulate replication among human $\beta$ cells, assuming that PDGF signals are the "missing link" in the replication of aged $\beta$ cells. Alternatively, PDGF signals may be just one piece of a complicated puzzle that ultimately determines the replicative capacity of $\beta$ cells as a function of age.

\section{How does $\beta$ cell mass expansion become restricted with age?}

As the above discussion illustrates, substantial evidence exists to support roles for specific molecular pathways in age-dependent restriction of cell cycle entry within $\beta$ cells. Nevertheless, it is unlikely that any single molecule or pathway will completely explain the effect of aging upon $\beta$ cell generation. To address this theoretical challenge, broader hypotheses must be considered. The following sections of this Review discuss the overarching themes of aging and developmental biology and propose specific hypotheses that might explain the limited cell cycle entry of $\beta$ cells or their progenitors in aged mammals.

Does extended cell cycle length limit $\beta$ cell mass expansion? Regeneration of $\beta$ cells may be limited by extended cell cycle length. Initial studies with neonatal rodent islets suggested that total cell cycle length (defined as the start of one cell division event to the next) was only a few hours and did not change with age (59). To examine $\beta$ cell regeneration, we carried out sequential thymidine-labeling studies in young mice. Although our study was primarily directed toward the goal of elucidating cell origins of adult $\beta$ cells, we also assessed the replicative history of adult $\beta$ cells over a long time span. Surprisingly, in young mice, $\beta$ cells that have just divided appear mostly incapable of immediately undergoing an additional round of cell division for a few months (8). We termed this phenomenon the replication refractory period to denote the prolonged $\mathrm{G}_{0}$ stage of cell cycle that prevents a subsequent round of cell division within those cells that have recently completed a previous round of cell division. Dor and colleagues have recently confirmed this observation in $\beta$ cells and pancreatic acinar cells, and further discovered that the replication refractory period appears to lengthen with age (60). Together, these two studies show that a very long cell cycle length may govern turnover of $\beta$ cells under basal or some regenerative conditions. Could the replication refractory period continue to lengthen in postnatal life and thus limit cell cycle entry in aged $\beta$ cells?

Does stochastic aging limit $\beta$ cell mass expansion? The age-dependent reduction in cell cycle entry of aged $\beta$ cells might be a form of somatic stem cell aging, as hypothesized to influence many other tissues (61). In this scenario, the replicative capacity of $\beta$ cells might "burn out" due to accumulation of DNA mutations that elicit checkpoints, ultimately resulting in the loss of $\beta$ cell regeneration capacity in aged mammals. Consequently, $\beta$ cell aging might be predicted to be a stochastic and cell-autonomous process. A corollary to this hypothesis is that $\beta$ cell-regenerative stimuli and signals might be fully present in aged mammals despite the lack of regenerative $\beta$ cell responses; augmentation of mitogenic signals might have little effect on $\beta$ cell mass expansion in aged mammals. Somatic aging of $\beta$ cells might also be subject to pathological stressors. For example, conditions that promote DNA damage such as reactive oxygen species might accelerate cell cycle exit among $\beta$ cells.
Alternatively, somatic aging of $\beta$ cells could be caused by organismal aging due to non-cell-autonomous processes, as observed by Rando and colleagues in aging muscle and liver (62). Notably the regenerative capacity of muscle and liver is only partially blunted by age, in contrast to the potent effects of age on $\beta$ cells. In aging muscle and liver, cell cycle exit of aged $\beta$ cells could result from lack of somatic growth factors, or from the accumulation of circulating growth inhibitors. Such systemic organismal aging would imply that restoration of somatic growth factors to youthful levels might allow cell cycle entry of aged $\beta$ cells.

Is adult $\beta$ cell mass expansion limited after puberty? Expansion of $\beta$ cells might slow or even cease in postpubertal adult life, in a manner equivalent to somatic growth of the skeleton and associated soft tissues. Prepubertal skeletal growth is powerfully regulated by pituitary-produced growth hormone, which acts to increase IGF-1 to promote growth of the skeleton and cartilaginous tissues (63). Pubertal estrogens accelerate the somatic skeletal growth response to IGF-1, but also act to mature the growth plate. As a result, the adult skeletal growth plate is ultimately rendered unresponsive to IGF-1. The dramatic decline in $\beta$ cell mass expansion with age suggests that islets could similarly undergo cell cycle exit. If so, islets could reach a mature total mass, after which further growth would be restricted. We have shown that $\beta$ cell mass expansion dramatically slows around one year of age in mice (38). Similarly, recent studies by Butler and colleagues revealed stable $\beta$ cell mass across the adult human life span (28). Notably, some organisms such as specific kinds of Osteichthyes (bony fish) exhibit slow somatic growth that continues well after sexual maturity; sturgeon continue to grow slowly decades after sexual maturity (64). Could adult human $\beta$ cells similarly harbor a capacity to slowly expand into adulthood? Interestingly, Butler and colleagues observe increased $\beta$ cell mass in obese subjects (28). Thus, it is possible that specific stimuli might expand aged $\beta$ cells under some circumstances. However, given the well-documented age-dependent decline in cell cycle entry within aged $\beta$ cells, how might $\beta$ cell mass expand in response to obesity? Self-renewal of pre-existing $\beta$ cells seems unlikely given low levels of $\beta$ cell turnover observed in aged subjects. Could tissue stem cells contribute to new $\beta$ cells in obese aged individuals? Alternatively, might $\beta$ cell mass expansion occur in obese adolescents, when $\beta$ cell regenerative capacity is robust? Such answers will require rigorous experimentation in aged model organisms.

\section{What will it take to regenerate human $\beta$ cells?}

Substantial challenges remain before regeneration of $\beta$ cell function can be safely achieved for diabetes patients. A diverse range of theories and opinions exist regarding the pathophysiology of age-related decline in cell cycle entry in $\beta$ cells. Clearly, not all of the above-mentioned theories will turn out to be correct, and much remains to be learned. Moreover, undiscovered factors and phenomena probably influence cell cycle entry of aged $\beta$ cells. The field must aggressively work to reconcile the vast body of disparate and seemingly opposing data regarding whether $\beta$ cells exit cell cycle and how this phenomena occurs. Successful human $\beta$ cell regeneration will require rigorous experimentation across a broad range of scientific disciplines and investigator perspectives. Sophisticated human islet xenotransplantation models or tissue banks from human surgical specimens will be essential to resolve the regenerative capacity of human $\beta$ cells. Due to the inherent challenges in conducting human islet studies, it will be important to conduct studies to independently confirm or refute high-pro- 
file hypotheses with complementary tools, additional model organisms, and animals from a broader range of ages. Widespread adoption of precise quantitative methodologies will also be critical to determine how many new $\beta$ cells are generated under various circumstances. Given recent evidence that a few $\beta$ cells in some aged mice attempt to expand under diabetic conditions, it seems possible that we may ultimately be able to expand $\beta$ cells in a safe and predictable manner.

\section{Acknowledgments}

The author thanks Jim Johnson, Ned Sharpless, Kourtney King, Matthew Rankin, and Carol Lam for thoughtful discussions; Rich- ard Aaron Cox, Larry Moss, and Peter Kushner for helpful comments on the manuscript; and Casey Blalock, Kathy Rogers, Denise Kettlewell, Lorena Herrera, Sandra Vale, and Stephanie Ramirez for their administrative expertise and support. Funding was received from the NIH (grants 1R01DK064101, 1R01AG040110, P30DK079638), JDRF, the Commonwealth of Pennsylvania (Center for Excellence in Regenerative Medicine grant 4100043362), and the Robert and Janice McNair Foundation.

Address correspondence to: Jake A. Kushner, Baylor College of Medicine, 6701 Fannin St., Suite 1020, Houston, Texas 77030, USA. Phone: 832.822.3780; Fax: 832.825.3909; E-mail: kushner@bcm.edu.
1. Bluestone JA, Herold K, Eisenbarth G. Genetics, pathogenesis and clinical interventions in type 1 diabetes. Nature. 2010;464(7293):1293-1300.

2. Fink RI, Kolterman OG, Griffin J, Olefsky JM Mechanisms of insulin resistance in aging. J Clin Invest. 1983;71(6):1523-1535.

3. Kahn SE, Hull RL, Utzschneider KM. Mechanisms linking obesity to insulin resistance and type 2 diabetes. Nature. 2006;444(7121):840-846.

4. Kahn SE, Zraika S, Utzschneider KM, Hull RL. The beta cell lesion in type 2 diabetes: there has to be a primary functional abnormality. Diabetologia. 2009; 52(6):1003-1012

5. Kahn BB. Type 2 Diabetes: When insulin secretion fails to compensate for insulin resistance. Cell. 1998; 92(5):593-596.

6. Rhodes CJ. Type 2 diabetes-a matter of beta-cell life and death? Science. 2005;307(5708):380-384.

7. Dor Y, Brown J, Martinez OI, Melton DA. Adult pancreatic beta-cells are formed by self-duplication rather than stem-cell differentiation. Nature. 2004 429(6987):41-46.

8. Teta M, Rankin MM, Long SY, Stein GM, Kushner JA. Growth and regeneration of adult Beta cells does not involve specialized progenitors. Dev Cell. 2007;12(5):817-826.

9. Brennand K, Huangfu D, Melton D. All beta cells contribute equally to islet growth and maintenance. PLoS Biol. 2007;5(7):e163.

10. Carlotti F, Zaldumbide A, Ellenbroek JH, Spijker HS, Hoeben RC, de Koning EJ. beta-Cell generation: can rodent studies be translated to humans? J Transplant. 2011;2011:892453.

11. Madsen LW, et al. GLP-1 receptor agonists and the thyroid: C-cell effects in mice are mediated via the GLP-1 receptor and not associated with RET activation. Endocrinology. 2012;153(3):1538-1547.

12. Koopman RJ, Mainous AG 3rd, Diaz VA, Geesey ME. Changes in age at diagnosis of type 2 diabetes mellitus in the United States, 1988 to 2000. Ann Fam Med. 2005;3(1):60-63.

13. Paulson RJ, et al. Pregnancy in the sixth decade of life: obstetric outcomes in women of advanced reproductive age. JAMA. 2002;288(18):2320-2323.

14. Niclauss $\mathrm{N}$, et al. Influence of donor age on islet isolation and transplantation outcome. Transplantation. 2011;91(3):360-366

15. Iozzo P, Beck-Nielsen H, Laakso M, Smith U, Yki-Jarvinen H, Ferrannini E. Independent influence of age on basal insulin secretion in nondiabetic humans. European Group for the Study of Insulin Resistance. J Clin Endocrinol Metab. 1999;84(3):863-868.

16. Chang AM, Halter JB. Aging and insulin secretion. Am J Physiol Endocrinol Metab. 2003;284(1):E7-E12.

17. Basu R, et al. Mechanisms of the age-associated deterioration in glucose tolerance: contribution of alterations in insulin secretion, action, and clearance. Diabetes. 2003;52(7):1738-1748.

18. Utzschneider KM, et al. Impact of intra-abdominal fat and age on insulin sensitivity and beta-cell function. Diabetes. 2004;53(11):2867-2872.

19. Maedler K, et al. Aging correlates with decreased beta-cell proliferative capacity and enhanced sensitivity to apoptosis: a potential role for Fas and pancreatic duodenal homeobox-1. Diabetes. 2006; 55(9):2455-2462.

20. Finegood DT, Scaglia L, Bonner-Weir S. Dynamics of $\beta$-cell mass in the growing rat pancreas. Diabetes. 1995;44(3):249-256.

21. Teta M, Long SY, Wartschow LM, Rankin MM, Kushner JA. Very slow turnover of beta-cells in aged adult mice. Diabetes. 2005;54(9):2557-2567.

22. Stolovich-Rain M, Hija A, Grimsby J, Glaser B, Dor Y. Pancreatic Beta cells in very old mice retain capacity for compensatory proliferation. J Biol Chem. 2012;287(33):27407-27414

23. Fan R, Kang Z, He L, Chan J, Xu G. Exendin-4 improves blood glucose control in both young and aging normal non-diabetic mice, possible contribution of beta cell independent effects. PLoS One. 2011;6(5):e20443

24. Cnop M, et al. The long lifespan and low turnover of human islet beta cells estimated by mathematical modelling of lipofuscin accumulation. Diabetologia. 2010;53(2):321-330.

25. Cnop M, Igoillo-Esteve M, Hughes SJ, Walker JN, Cnop I, Clark A. Longevity of human islet alpha- and beta-cells. Diabetes Obes Metab. 2011; 13(suppl 1):39-46.

26. Perl S, et al. Significant human beta-cell turnover is limited to the first three decades of life as determined by in-vivo thymidine analog incorporation and radiocarbon dating. $J$ Clin Endocrinol Metab. 2010;95(10):E234-E239.

27. Meier JJ, et al. Beta-cell replication is the primary mechanism subserving the postnatal expansion of beta-cell mass in humans. Diabetes. 2008; 57(6):1584-1594.

28. Saisho Y, Butler AE, Manesso E, Elashoff D, Rizza RA, Butler PC. beta-cell mass and turnover in humans: effects of obesity and aging. Diabetes Care. 2013;36(1):111-117.

29. Gregg BE, et al. Formation of a human beta-cell population within pancreatic islets is set early in life. J Clin Endocrinol Metab. 2012;97(9):3197-3206.

30. Sachdeva MM, Stoffers DA. Minireview: Meeting the demand for insulin: molecular mechanisms of adaptive postnatal beta-cell mass expansion. Mol Endocrinol. 2009;23(6):747-758.

31. Desgraz R, Bonal C, Herrera PL. beta-cell regeneration: the pancreatic intrinsic faculty. Trends Endocrinol Metab. 2011;22(1):34-43.

32. Granger A, Kushner JA. Cellular origins of beta-cell regeneration: a legacy view of historical controversies. J Intern Med. 2009;266(4):325-338.

33. Herrera PL, et al. Ablation of islet endocrine cells by targeted expression of hormone-promoterdriven toxigenes. Proc Natl Acad Sci U S A. 1994; 91(26):12999-13003.

34. Nir T, Melton DA, Dor Y. Recovery from diabetes in mice by beta cell regeneration. J Clin Invest.
2007;117(9):2553-2561.

35. Thorel F, et al. Conversion of adult pancreatic alpha-cells to beta-cells after extreme beta-cell loss. Nature. 2010;464(7292):1149-1154.

36. Kilborn SH, Trudel G, Uhthoff H. Review of growth plate closure compared with age at sexual maturity and lifespan in laboratory animals. Contemp Top Lab Anim Sci. 2002;41(5):21-26.

37. Horton JA, Bariteau JT, Loomis RM, Strauss JA, Damron TA. Ontogeny of skeletal maturation in the juvenile rat. Anat Rec (Hoboken). 2008; 291(3):283-292.

38. Rankin MM, Kushner JA. Adaptive beta-cell proliferation is severely restricted with advanced age. Diabetes. 2009;58(6):1365-1372.

39. Tschen SI, Dhawan S, Gurlo T, Bhushan A. Age-dependent decline in beta-cell proliferation restricts the capacity of beta-cell regeneration in mice. Diabetes. 2009;58(6):1312-1320.

40. Saisho Y, et al. Ongoing beta-cell turnover in adult nonhuman primates is not adaptively increased in streptozotocin-induced diabetes. Diabetes. 2011; 60(3):848-856

41. Chen X, Zhang X, Chen F, Larson CS, Wang LJ, Kaufman DB. Comparative study of regenerative potential of beta cells from young and aged donor mice using a novel islet transplantation model. Transplantation. 2009;88(4):496-503.

42. Tian L, et al. Comparison of exendin-4 on betacell replication in mouse and human islet grafts. Transpl Int. 2011;24(8):856-864.

43. Wong ES, et al. p38MAPK controls expression of multiple cell cycle inhibitors and islet proliferation with advancing age. Dev Cell. 2009;17(1):142-149.

44. Vasavada RC, Gonzalez-Pertusa JA, Fujinaka Y, Fiaschi-Taesch N, Cozar-Castellano I, Garcia-Ocana A. Growth factors and beta cell replication. Int J Biochem Cell Biol. 2006;38(5-6):931-950.

45. Gunasekaran U, Gannon M. Type 2 diabetes and the aging pancreatic beta cell. Aging (Albany NY). 2011;3(6):565-575

46. Kulkarni RN, Mizrachi EB, Ocana AG, Stewart AF. Human beta-cell proliferation and intracellular signaling: driving in the dark without a road map. Diabetes. 2012;61(9):2205-2213.

47. Krishnamurthy J, et al. Ink $4 a /$ Arf expression is a biomarker of aging. J Clin Invest. 2004; 114(9):1299-1307.

48. Krishnamurthy J, et al. p16INK4a induces an age-dependent decline in islet regenerative potential. Nature. 2006;443(7110):453-457.

49. Janzen V, et al. Stem-cell ageing modified by the cyclin-dependent kinase inhibitor p16INK4a. Nature. 2006;443(7110):421-426.

50. Molofsky AV, et al. Increasing p16INK4a expression decreases forebrain progenitors and neurogenesis during ageing. Nature. 2006;443(7110):448-452.

51. Saxena R, et al. Genome-wide association analysis identifies loci for type 2 diabetes and triglyceride levels. Science. 2007;316(5829):1331-1336.

52 . Scott LJ, et al. A genome-wide association study of 
type 2 diabetes in Finns detects multiple susceptibility variants. Science. 2007;316(5829):1341-1345. 53. Zeggini E, et al. Replication of genome-wide association signals in UK samples reveals risk loci for type 2 diabetes. Science. 2007;316(5829):1336-1341.

54 . Pascoe J, et al. Free fatty acids block glucose-induced beta-cell proliferation in mice by inducing cell cycle inhibitors p16 and p18. Diabetes. 2012; 61(3):632-641.

55. Dhawan S, Tschen SI, Bhushan A. Bmi-1 regulates the Ink $4 \mathrm{a} /$ Arf locus to control pancreatic beta-cell proliferation. Genes Dev. 2009;23(8):906-911.

56. Chen $\mathrm{H}$, et al. Polycomb protein Ezh2 regulates pancreatic beta-cell Ink4a/Arf expression and regeneration in diabetes mellitus. Genes Dev. 2009;
23(8):975-985.

57. Gilbert ER, Liu D. Epigenetics: The missing link to understanding beta-cell dysfunction in the pathogenesis of type 2 diabetes. Epigenetics. 2012; 7(8):841-852.

58. Chen $\mathrm{H}$, et al. PDGF signalling controls age-dependent proliferation in pancreatic beta-cells. Nature. 2011;478(7369):349-355.

59. Swenne I. Effects of aging on the regenerative capacity of the pancreatic B-cell of the rat. Diabetes. 1983;32(1):14-19.

60. Salpeter SJ, Klein AM, Huangfu D, Grimsby J, Dor Y. Glucose and aging control the quiescence period that follows pancreatic beta cell replication. Development. 2010;137(19):3205-3213.
61. Sharpless NE, DePinho RA. How stem cells age and why this makes us grow old. Nat Rev Mol Cell Biol. 2007;8(9):703-713.

62. Conboy IM, Conboy MJ, Wagers AJ, Girma ER, Weissman IL, Rando TA. Rejuvenation of aged progenitor cells by exposure to a young systemic environment. Nature. 2005;433(7027):760-764.

63. Nilsson O, Marino R, De Luca F, Phillip M, Baron J. Endocrine regulation of the growth plate. Horm Res. 2005;64(4):157-165.

64. Balazik MT, Garman GC, Fine ML, Hager CH, McIninch SP. Changes in age composition and growth characteristics of Atlantic sturgeon (Acipenser oxyrinchus oxyrinchus) over 400 years. Biol Lett. 2010;6(5):708-710. 